\title{
Physical Distancing and Social Media Shopping
}

\author{
Alhapen Ruslin Chandra*, Afifah, Yudhytia Wimeina, Abdiani Khairat \\ Business Administration Department \\ Politeknik Negeri Padang \\ Padang, Indonesia \\ *alhapen@polinpdg.ac.id
}

\begin{abstract}
The outbreak of Covid-19 has encouraged consumers to shop online to overcome physical distancing. This study aims to investigate how consumers use social media applications on their smartphones to shop for groceries online. Data was collected during Indonesia's large-scale prohibition of social distancing on May 2020. Using the Partial Least Square Structural equation modelling approach, it is known that the usability and ease of social media applications that can be used to shop online on consumer's smartphone influence towards using social media applications on smartphones for grocery shopping. Attitude is a significant mediator between the perception of usefulness and perceived ease of use of social media applications on smartphones, and the intention to purchase groceries online.
\end{abstract}

Keywords-physical distancing, social media, smartphone, online shoping

\section{INTRODUCTION}

The outbreak of the Covid-19 virus in early 2020, made people reduce their activities. People were not allowed to meet or gather with many people in a certain place. The government, both central and regional, urges the public to avoid crowds. Learning, working and worship activities should be done at home. This was the way to prevent the spread of the corona viruses which can cause disease and even the risk of death. One of the places that many people gather is a shop, mini market, supermarket, and traditional market where consumers could buy what their needs at that place.

Due to governmental regulation to stay at home, people would have a problem if they wanted to buy the products they need since they could not access the seller's place. However, existence of smartphones and social media applications could be used to connect consumers and retailers. Many sellers also provided online service for consumer who need their service. Along with social distancing and physical distancing regulation, consumers could use the social media application to shop online certain product their need including food.

Most consumers in developing countries, tend to use offline transactions [1]. However, covid-19 pandemic prevents consumer from face to face transaction. It leads consumers to use online shopping application to purchase their need. This situation demonstrated a need to study how consumer use their social media application for online shopping. Particularly, this study investigated how consumers perceive the use and ease of using cellular technology on attitudes to using social media applications that affect the intention to purchase online for foodstuff during the large-scale social restrictions (semilockdown) during Covid 19-pandemic.

\section{LITERATURE REVIEW}

Online purchasing behaviour is related to how customers make decisions, to buy online goods or services they need [2]. Online shopping is a process in which customers buy goods and services directly from sellers using the internet either through websites, applications provided by providers, or through social media applications. Intention of customers to shop online is a cognitive planning within a certain period $[3,4]$.

Customer behaviour intentions can be used to predict actual behaviour [3]. Online shopping intention is a significant predictor of online purchasing decisions [5]. Thus, it is important to study online shopping intentions for marketers to predict actual buying behaviour and to develop effective marketing strategies. The development of information technology, especially in smartphone technology, has changed the pattern of relationships between humans. Likewise, in marketing, with applications in their smartphone, consumers can change the relationship with producers [6]. Consumers can access product information and make purchases using applications on their mobile phones without using a computer or laptop [7].

Technology Acceptance Model is a model, widely used for examining customer engagement with technology development [8] and their intention to continue using it [9]. This study implements the Technology Acceptance Model (TAM) because it can predict customer intentions. TAM is a good model used to examine technology acceptance and adaptation by customers in their behaviour related to the use of the technology [10]. The two concepts studied with TAM are usability and ease of use towards application-use attitudes that affect online shopping intentions. This study builds a model by proposing the perceived usefulness and perceived ease of use variables as the main components of TAM.

TAM can be used to understand customer attitudes towards technology use [11]. TAM proposes two concepts, namely: 
ease of use and perceived benefits [12] whereby each factor collectively represents a major factor influencing attitudes towards smartphone application usage [13]. This model consistently finds that ease of use and perceived benefits contribute the most to successful use of mobile phone applications [14]. Perceived usefulness described the extent of customers will believe that using a specific technology can create a significant value for them [15]. TAM states that the initial behavioural intention to adopt a mobile application is determined by one's attitude towards the use of that system and the perception of its usefulness, where attitude is a direct function of usability [16]. TAM also states that people use human representations to assess the fit between task objectives and the resulting consequences as a basis for forming judgments about user-performance relationships, that is, consumers' perceived usefulness [17]. If consumers understand that using the application will be beneficial and satisfy their needs, then they will take a positive attitude $[9,15,18]$. Usability as an antecedent of traditional technology adoption explains the owner's intention to use smartphone applications [9]. Therefore, this study proposed the first hypothesis as follows:

H1. Perceived usefulness has a positive impact on attitudes towards using social media applications on smartphones for grocery shopping.

Attitude is a cognitive reaction to an action which an indication of how hard people are willing to try and how much effort they are planning to put in Baek [19]. Perceived ease of use refers to the degree to which a person believes technology is easy to use [20]. Individuals use a new technology because of the perceived extrinsic benefits, such as usability and ease of use, as well as intrinsic benefits such as: benefits and hedonic [13]. Many studies have described the positive effects of the easiness and convenience of digital technology [20-22]. The use of TAM in the context of information systems has shown that practicality has a significant positive effect on behaviour towards mobile application usage [23]. Therefore, the second hypothesis is:

H2. Perceived ease of use positively influences attitudes towards using social media applications on smartphones for grocery shopping.

Individual intention to carry out an activity in the context of a mobile application is determined by their attitude towards the application [24]. It affects the intention to buy for two main reasons: first, users do not typically see mobile applications as an interruption of their mobile experience, and secondly, mobile applications are expected to offer a targeted experience to users and provide products at a much lower price [25]. The persuasive effect of the application, developed in customer relationship management practices, can influence user attitudes towards usage and purchase intentions. By logging into an application, customers engage in multiple points of contact with the product, such as sharing information and making purchases [9]. A positive attitude towards using the application increases the number of users who are likely to visit the application and the duration increases with each visit. This leads to increased proximity and increases the purchase intention of potential consumers [22]. The use of a welldesigned application will increase the positive attitude of customers, which will increase the intention to buy additional products or services [26,27]. Thus, this study proposes a hypothesis:

H3. Attitudes towards the use of social media applications on smartphones affect the intention to shop for groceries.

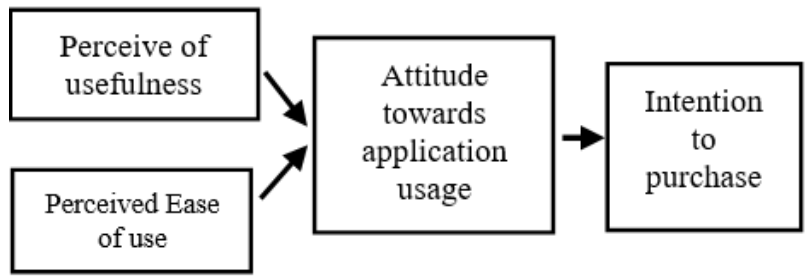

Fig. 1. Research conceptual model.

\section{METHOD}

\section{A. Sample}

Sample of this research is smartphone users in West Sumatra, consist of housewives or those who are responsible for purchasing food for household needs online, using social media applications on smartphones. Data were processed by Partial Least Square Structural Equation Modelling (PLSSEM). The sample required when using SEM is 300 [28]. Other experts recommend that the N: q ratio should be 20 to 1 , or 20 observations (samples) for each estimated parameter in the model [29], 10 to 1 [30] or 5 to 1 [31]. Since this research has 4 constructs, using recommendation [29], 80 samples are required.

To facilitate data collection, this research will utilize information technology by distributing questionnaires online. Data collection was carried out from 5 May to 30 May 2020, when large-scale social restrictions occurred (semi lockdown) in Indonesia. Of the 146 respondents, 102 respondents finally met the requirements for sample, which consists of $80.39 \%$ women and $19.61 \%$ men. Educational backgrounds of respondents are high school 7.84\%, $40.20 \%$ undergraduate, and postgraduate $51.96 \%$. The respondent occupation are $48.04 \%$ government employees, $23.53 \%$ company employees, $8.82 \%$ entrepreneur, $12.75 \%$ student, $4.90 \%$ do not work, and $1.96 \%$ household. Most of them spend 5 million to 10 million IDR per month for shopping $(48.04 \%)$, and less than 5 million (32.35\%), the rest spend 10 million to 20 million (11.76\%) and more than 20 million IDR per month $(7.84 \%)$

\section{B. Measurement}

This study adopts measurement items from studies conducted by previous researchers. From the constructs in the research model, measurement was carried out using certain items. The scale items that show the perceived usefulness and perceived ease of use of the application are taken from 
Kucukusta et al [32], which includes ease, benefit, speed, efficiency, and simplicity. Attitude items towards the use of social media applications on smartphones are adopted from [33], which includes pleasure, benefits, value, and positive attitudes, while the purchase intention item comes from a study [34] which includes likes, tries and purchases. The measurement uses a Likert scale, ranging from $1=$ strongly disagree to $5=$ strongly agree .

TABLE I. MEASUREMENT INSTRUMENT

\begin{tabular}{|c|c|}
\hline Variable & Measurement Item \\
\hline $\begin{array}{l}\text { Perceived } \\
\text { Usefulness }\end{array}$ & $\begin{array}{l}\text { - Social media applications can make } \\
\text { online shopping for food easier (Use1) } \\
\text { - Application is useful to shop for } \\
\text { groceries online (Use2) } \\
\text { - Application helps me shop for } \\
\text { groceries online faster (Use3) } \\
\text { - Application helps me shop for } \\
\text { groceries more efficiently (Use4) }\end{array}$ \\
\hline $\begin{array}{l}\text { Perceived } \\
\text { ease of use }\end{array}$ & $\begin{array}{l}\text { - Applications can be easily learned to } \\
\text { shop for groceries online (Easy1) } \\
\text { - Does not require big efforts to use the } \\
\text { application (Easy2) } \\
\text { - Can easily use the application to shop } \\
\text { for groceries online (Easy3) } \\
\text { - Application work steps, can be easily } \\
\text { followed (Easy 4) }\end{array}$ \\
\hline $\begin{array}{l}\text { Attitude } \\
\text { towards } \\
\text { social } \\
\text { media } \\
\text { application } \\
\text { for online } \\
\text { shopping }\end{array}$ & $\begin{array}{l}\text { - I am happy to use the application to } \\
\text { shop for groceries online (Atti1) } \\
\text { - Application is useful for buying } \\
\text { groceries online (Atti2) } \\
\text { - Application is valuable since it can } \\
\text { connect to seller's directly (Atti3) } \\
\text { - I can find out food products that are } \\
\text { sold online by the seller through the } \\
\text { application (Atti4) } \\
\text { - I have a good attitude towards } \\
\text { applications (Atti5) }\end{array}$ \\
\hline $\begin{array}{l}\text { Intention to } \\
\text { purchase } \\
\text { using social } \\
\text { media } \\
\text { application }\end{array}$ & $\begin{array}{l}\text { - Most likely I will continue to buy } \\
\text { groceries online using the app (Int1) } \\
\text { - I will use the application, to buy } \\
\text { online if I need groceries (Int2) } \\
\text { - I will always shop online for groceries } \\
\text { using this application (Int3) }\end{array}$ \\
\hline
\end{tabular}

\section{RESULTS}

\section{A. Reliability and Validity}

Reliability of all constructs was tested using the Cronbach's Alpha and Composite Reliability (CR) measurement. If the value is greater than 0.7 indicates that the model has internal consistency [35]. The measurement of convergent validity is measured by Average Variance Extracted (AVE). Value greater than 0.75 indicates the reliability of the measurement model [35].
TABLE II. MEASUREMENT PROPERTY

\begin{tabular}{|l|l|l|l|l|l|}
\hline Construct & Item & $\begin{array}{c}\text { Factor } \\
\text { Loading }\end{array}$ & $\begin{array}{c}\text { Cronbach' } \\
\text { s Alpha }\end{array}$ & CR & AVE \\
\hline \multirow{4}{*}{$\begin{array}{l}\text { Perceived } \\
\text { Usefulness }\end{array}$} & Use1 & 0.807 & 0.871 & 0.912 & 0.772 \\
\hline & Use2 & 0.885 & & & \\
\cline { 2 - 6 } & Use3 & 0.879 & & & \\
\cline { 2 - 6 } & Use4 & 0.824 & & & \\
\hline \multirow{2}{*}{$\begin{array}{l}\text { Perceived } \\
\text { ease of use }\end{array}$} & Easy1 & 0.852 & 0.905 & 0.934 & 0.779 \\
\cline { 2 - 6 } & Easy2 & 0.837 & & & \\
\cline { 2 - 6 } & Easy3 & 0.922 & & & \\
\cline { 2 - 6 } & Easy4 & 0.918 & & & \\
\hline \multirow{2}{*}{$\begin{array}{l}\text { Attitude } \\
\text { sowards } \\
\text { social } \\
\text { media } \\
\text { application }\end{array}$} & Atti1 & 0.859 & 0.901 & 0.927 & 0.717 \\
\cline { 2 - 6 } & Atti2 & 0.850 & & & \\
\cline { 2 - 6 } & Atti3 & 0.859 & & & \\
\cline { 2 - 6 } $\begin{array}{l}\text { Intention } \\
\text { to } \\
\text { purchase }\end{array}$ & Atti5 & 0.815 & & & \\
\cline { 2 - 6 } & Int1 & 0.851 & & & \\
\cline { 2 - 6 } & Int3 & 0.871 & 0.857 & 0.913 & 0.779 \\
\hline
\end{tabular}

Table 2 shows that all loading factors of each item are greater than the cut off value of 0.50 [35]. The Cronbach Alpha $(\alpha)$ and Composite Reliability (CR) values are also greater than 0.7. This shows the reliability of the outer measurement model [35]. The average variance extracted (AVE) value of the variable has a greater cut off value of 0.50 , indicating that the measurement model has convergent validity [35].

Discriminant validity is measured by comparing AVE square roots of each construct with the correlation between constructs. Table 3 shows that the value below the diagonal is the correlation between variables, while the diagonal value is the square root of AVE. All values that are under the diagonal are smaller than the diagonal values, which indicates that the measurement model has good discriminant validity.

\section{TABLE III. CORRELATION BETWEEN VARIABLES}

\begin{tabular}{|l|l|l|l|l|}
\hline & Intention & Ease to use & Attitude & Usefulness \\
\hline Intention & 0,882 & & & \\
\hline Ease to use & 0,563 & 0,883 & & \\
\hline Attitude & 0,776 & 0,729 & 0,847 & \\
\hline Usefulness & 0,658 & 0,731 & 0,743 & 0,849 \\
\hline
\end{tabular}

\section{B. Hypothesis Testing}

To test the hypothesis, a bootstrapping approach is used [36]. Results of this approach is described in Table 4.

TABLE IV. HYPOTHESIS TEST

\begin{tabular}{|c|c|c|c|c|}
\hline Path & Std Beta & $\begin{array}{c}T \\
\text { statistic } \\
\end{array}$ & P Value & Result \\
\hline $\begin{array}{l}\text { Usefulness } \rightarrow \\
\text { Attitude }\end{array}$ & 0.348 & 4.44 & 0.000 & Supported \\
\hline $\begin{array}{l}\text { Ease to use } \rightarrow \\
\text { Attitude }\end{array}$ & 0.383 & 4.47 & 0.000 & Supported \\
\hline $\begin{array}{ll}\text { Attitude } \\
\text { intention }\end{array} \quad \rightarrow$ & 0.764 & 11.50 & 0.000 & Supported \\
\hline
\end{tabular}

Hypothesis 1 predicts that perceived usefulness has a positive effect on attitudes towards the use of social media applications on smartphones for grocery shopping. The test results showed statistically significant $(\beta=0.348$ and $\mathrm{T}$ statistic $=4.44$ with $\mathrm{p}<0.05)$. Thus Hypothesis 1 is accepted. 
Likewise, Hypothesis 2 predicts that perceived ease of use positively affects attitudes towards using social media applications on smartphones for grocery shopping. The test showed statistically significant $(\beta=0.383$ and T statistic $=4.47$ with $\mathrm{p}<0.05)$. Hypothesis 3 which predicts that attitudes towards the use of social media applications on smartphones affect the intention to buy online is also statistically significant $(\beta=0.764$ and $\mathrm{T}$ statistic $=11.50$ with $\mathrm{p}<0.05)$. Thus Hypothesis 2 and Hypothesis 3 are also accepted.

\section{Mediation Effects}

Testing the mediating effect of attitudes between perceived usefulness and intention to purchase as well as between perceived ease to use and intention to purchase is carried out using the indirect effect approach and the bias-corrected bootstrap confidence intervals [37].

TABLE V. HYPOTHESIS TEST FOR MEDIATOR VARIABLES

\begin{tabular}{|c|c|c|c|c|c|}
\hline & Mediator & $\begin{array}{c}\text { Indirect } \\
\text { path } \\
\text { coefficient }\end{array}$ & $\begin{array}{c}P \\
\text { Value }\end{array}$ & $\begin{array}{c}\text { Lower } \\
2.5 \%\end{array}$ & $\begin{array}{l}\text { Upper } \\
97.5 \%\end{array}$ \\
\hline $\begin{array}{l}\text { Usefulness } \\
\rightarrow \text { intention }\end{array}$ & Attitude & 0.348 & 0.000 & 0.192 & 0.503 \\
\hline $\begin{array}{l}\text { Ease of } \\
\text { use } \rightarrow \text { intenti } \\
\text { on }\end{array}$ & Attitude & 0.295 & 0.000 & 0.138 & 0.458 \\
\hline
\end{tabular}

The results indicate that the indirect effect of perceived usefulness on intention to shop online is significant. The biascorrected bootstrap confidence intervals of the mediator differ by zero $(0.192$ to 0.503$)$. Thus, attitude is a significant mediator between the consumer's perceived usefulness and intention to purchase. Table 4 also shows that the direct effect of perceived usefulness is also significant on attitudes. This indicates that attitude plays a mediating role between perceived usefulness and intention to purchase online using social media application on smartphone.

Likewise, for the perceived ease of use variable. The indirect effect of perceived ease of use on the intention to shop online is significant. The bias-corrected bootstrap confidence intervals of the stance mediators differ by zero ( 0.192 to 0.503). Thus, attitude is a significant mediator between consumers' perceptions of ease of use and intention to shop online using social media application on smartphone. The direct effect of perceived ease of use is also significant on attitudes (Table 4). Thus, attitude mediates the relationship between perceived ease of use with intention to shop online using social media application in smartphone.

\section{CONCLUSION}

This study aims to determine how consumers use social media applications on their smartphones to shop for groceries online during a period of large-scale social distancing due to the Covid-19 outbreak. This study found that perceived usefulness has a positive effect on attitudes towards using social media applications on smartphones to shop grocery online. It supports study $[9,15,18]$ which found that consumers who take benefit from using the application to fulfil their needs, will take a positive attitude toward the application.

Likewise, the perception of ease of use positively affects attitudes towards using social media applications on smartphones, in line with [20-23]. Furthermore, the attitude towards the use of social media applications on smartphones influencing the intention to shop for groceries online is also statistically significant. This result similar with study $[22,26,27]$.

Attitude is a significant mediator between the perception of usefulness of social media applications on smartphones and intention to purchase online for groceries. This study also proves that attitude is also a significant mediator between the perceived ease of use of social media applications on smartphones and the intention to buy for groceries online.

Furthermore, during semi lock down or largescale prohibition of social distancing in Indonesia, the perceive usefulness and perceived ease of use led consumer have a positive attitude toward utilization of social media application on their smartphone to purchase grocery food they need. Therefore, marketers must take advantage by using social media applications for selling their products.

\section{ACKNOWLEDGEMENT}

Authors thanks to Ministry of Education and Culture of Republic of Indonesia, and Politeknik Negeri Padang for funding this research.

\section{REFERENCES}

[1] N. Peña-García, I. Gil-Saura, A. Rodríguez-Orejuela and J.R. SiqueiraJunior, "Purchase intention and purchase behavior online: A crosscultural approach," Heliyon, vol. 6, no. 6, pp. e04284, 2020.

[2] P. Kotler and K.L. Keller, Marketing Management. New Jersey, US, 2012.

[3] A. Mandilas, A. Karasavvoglou, M. Nikolaidis and L. Tsourgiannis, "Predicting consumer's perceptions in on-line shopping," Procedia Technology, vol. 8, pp. 435-444, 2013

[4] P.A. Pavlou, "Consumer acceptance of electronic commerce: Integrating trust and risk with the technology acceptance model," Int. J. Elec. Com, vol. 7, no. 3, pp. 101-134, 2003.

[5] Y.H. Chen, I.C. Hsu and C. C. Lin, "Website attributes that increase consumer purchase intention: A conjoint analysis," J. Bus. Res, vol. 63 , no. 9-10, pp. 1007-1014, 2010

[6] V. Viswanathan, L.D. Hollebeek, E.C. Malthouse, E. Maslowska, S Jung Kim and W. Xie, "The dynamics of consumer engagement with mobile technologies," Serv. Sci, vol. 9, no. 1, pp. 36-49, 2017.

[7] V. Verma, D. Sharma and J. Sheth, "Does relationship marketing matter in online retailing? A meta-analytic approach," J. Acad. Mark. Sci., vol. 44, no. 2, pp. 206-217, 2016.

[8] A. Tarute, S. Nikou and R. Gatautis, "Mobile application driven consumer engagement," Telematics and Informatics, vol. 34, no.4, pp. 145-156, 2017.

[9] S. Lee, "Enhancing customers' continued mobile app use in the service industry,” J. Serv, Mark., vol. 6, pp. 680-691, 2018. 
[10] B. Hernandez, J. Jiménez and M.J. Martín, "Customer behavior in electronic commerce: The moderating effect of e-purchasing experience,” J. Bus. Res., vol. 63, no. 9-10, pp.964-971, 2010.

[11] M. Rivera, A. Gregory and L. Cobos, "Mobile application for the timeshare industry: the influence of technology experience, usefulness, and attitude on behavioral intentions," J. Hosp. Tour, Tech., vol. 6, no. 3, pp. 242-257, 2015.

[12] D.J. McFarland and D. Hamilton. "Adding contextual specificity to the technology acceptance model," Comp. Hum. Beh., vol. 22, no. 3, pp. 427-447, 2006.

[13] S. Kim, T.H. Baek, Y.K. Kim and K. Yoo, "Factors affecting stickiness and word of mouth in mobile applications," J. Res. Bus. Inter. Mark., vol. 10, no. 3, pp. 177-192, 2016.

[14] I. Pentina, E.B. Pullins and J.W. Wilkinson, "Comparing drivers of social media marketing adoption by salespeople in Australia and the USA: a pilot study,” Int. J. Infor. Sys. Man., vol. 1, no. 1-2, pp. 146-165, 2014.

[15] S.A. Olaleye, J. Salo, I.T. Sanusi and A.O. Okunoye, "Retailing Mobile App Usefulness: Customer Perception of Performance, Trust and Tension Free," Int. J. E-Serv Mob. Appl. (IJESMA), vol. 10, no. 4, pp. 1-17, 2018.

[16] A. Gupta and N. Arora, "Understanding determinants and barriers of mobile shopping adoption using behavioral reasoning theory," J. Retail. Cons. Serv., vol. 36, pp. 1-7, 2017.

[17] V. Venkatesh and F.D. Davis, "A theoretical extension of the technology acceptance model: Four longitudinal field studies," Man. Sci., vol. 46 no. 2, pp. 186-204, 2000.

[18] C. Morosan and A. DeFranco, "Modeling guests' intentions to use mobile apps in hotels, ” Int. J. Cont Hosp. Man., vol. 28, no. 9, pp. 1968 1991, 2016.

[19] Y. Baek, "Analysis of user's attitude toward apps, intention to use and continual consuming intention: Focused on mobile commerce," Int. J. Cont., vol. 9, no. 4, pp. 35-44, 2013.

[20] J.M.C. Verissimo, "Enablers and restrictors of mobile banking app use: A fuzzy set qualitative comparative analysis (fsQCA)," J Bus. Res., vol. 69 , no. 11 pp. $5456-5460,2016$.

[21] M. Gill, S. Sridhar and R. Grewal, "Return on engagement initiatives: A study of a business-to-business mobile app,” J. Mark., vol. 81, no. 4, pp. 45-66, 2017.

[22] C.L. Hsu and J.C.C. Lin, "Effect of perceived value and social influences on mobile app stickiness and in-app purchase intention,” Tech. Forec. Soc. Ch., vol. 108, pp. 42-53, 2016.
[23] D.H. Kim, S.H. Ha and K. Park, "Antecedent Factors Influencing the Continued Use of Smart Banking by Different Mobile Platforms: Android OS vs. iOS,” J. Inf. Sys., vol. 24, no. 2, pp. 209-240, 2015.

[24] S. Carter and A.C.M. Yeo, "Mobile apps usage by Malaysian business undergraduates and postgraduates," Internet Res., vol. 26, no. 3, pp. 733-757, 2016

[25] I. Alnawas and F. Aburub, "The effect of benefits generated from interacting with branded mobile apps on consumer satisfaction and purchase intentions,” J. Ret. Cons. Serv., vol. 31, pp. 313-322, 2016.

[26] S.J. Kim, R.J.H. Wang and E.C. Malthouse, "The effects of adopting and using a brand's mobile application on customers' subsequen purchase behavior,” J. Inter. Mark., vol. 31, pp. 28-41, 2015.

[27] S. Bellman, R.F. Potter, S. Treleaven-Hassard, J.A. Robinson and Varan, D. Bellman, "The effectiveness of branded mobile phone apps," J. Inter. Mark., vol. 25, no. 4, pp. 191-200, 2011.

[28] B.G. Tabachnick and L.S. Fidell, Using Multivariate Statistics. Pearson, 2013.

[29] R.B. Kline, Principles and practice of structural equation modelling. Guilford Pub, 2015.

[30] J.B. Schreiber, A. Nora, F.K. Stage, E.A. Barlow and J. King, "Reporting structural equation modeling and confirmatory factor analysis results: A review," J. Edu. Res., vol. 99, no. 6, pp. 323-338, 2006

[31] P.M. Bentler and C.P. Chou, "Practical issues in structural modelling," Soc. Met. Res., vol. 16, no. 1, pp. 78-117, 1987.

[32] D. Kucukusta, R. Law, A. Besbes and P. Legoherel, "Re-examining perceived usefulness and ease of use in online booking," Int. J. Con. Hosp. Man., 2015

[33] C.Y. Lee, C.H. Tsao and W.C. Chang, "The relationship between attitude toward using and customer satisfaction with mobile application services,” J. Enter. Inf. Man., vol. 28, no.5, pp. 680-697, 2015

[34] I. Erkan and C. Evans, "The influence of eWOM in social media on consumers' purchase intentions: An extended approach to information adoption," Comp. Hum. Beh., vol. 61, pp. 47-55, 2016

[35] J.F. Hair, W.C. Black, B.J. Babin, R.E. Anderson and R.L. Tatham, Multivariate data analysis. England: Essex, 2014

[36] W.W. Chin, How to write up and report PLS analyses. Handbook of partial least squares. Springer, Berlin, Heidelberg, pp. 655-690, 2010

[37] C. Nitzl, J.L. Roldan and G. Cepeda, "Mediation analysis in partial least squares path modelling," Ind. Man. Data Anal., vol. 116, no. 9, pp. 1849-1864, 2016. 